\title{
高波浪時における碟浜の変形と越波・浜崖形成 防止に有効な養浜形状の検討 LONGITUDINAL CHANGE OF GRAVEL BEACH UNDER STORM WAVE CONDITION AND BEACH PROFILE PREVENTING WAVE OVERTOPPING
}

\author{
岡田昌之 ${ }^{1} \cdot$ 田中浩充 ${ }^{2} \cdot$ 宇多高明 $^{3} \cdot$ 石川仁憲 $^{4} \cdot$ 三波俊郎 ${ }^{5} \cdot$ \\ 芹沢真澄 ${ }^{6} \cdot$ 神田康嗣 $^{7}$ \\ Masayuki OKADA, Hiromitsu TANAKA, Takaaki UDA, Toshinori ISHIKAWA, \\ Toshiro SAN-NAMI, Masumi SERIZAWA and Yasuji KANDA
}

\author{
1国土交通省中部地方整備局静岡河川事務所長（干311-2424 静岡県静岡市葵区田町3-108） \\ 2国土交通省中部地方整備局静岡河川事務所海岸課長（３311-2424 静岡県静岡市葵区田町3-108） \\ 3正会員 工博 (財) 土木研究センター常務理事なぎさ総合研究室長兼日本大学客員教授理工学部海洋 \\ 建築工学科（干110-0016 東京都台東区台東1-6-4) \\ 4正会員 工修 （財）土木研究センターなぎさ総合研究室（干110-0016 東京都台東区台東1-6-4） \\ 5海岸研究室（有）（干160-0011 東京都新宿区若葉1-22 ローヤル若葉301） \\ ${ }^{6}$ 正会員 海岸研究室（有）（†160-0011 東京都新宿区若葉1-22ローヤル若葉301） \\ 7正会員（株）水域ネットワーク（† 134-0088 東京都江戸川区西葛西6-8-10 朝日生命西葛西ビル6F）
}

\begin{abstract}
On October 8, 2009, storm waves with a significant wave height of $\mathrm{H}_{1 / 3}=6.51 \mathrm{~m}(\mathrm{~T}=12.8 \mathrm{~s})$ associated with Typhoon 18 attacked the Suruga coast facing Suruga Bay. The site observation was carried out after the storm. High beach ridge was formed on the gravel beach due to the shoreward sand transport. Wave overtopping to the seawall occurred at the site where the difference between the top of the seawall and the ground elevation of the nourishment beach is small. Measured beach profile changes were reproduced using the contour-line-change model. The effect of the difference in the backshore height to wave overtopping was investigated using the CADMAS-SURF model.
\end{abstract}

Key Words : Suruga coast, gravel beach, wave overtopping, beach nourishment, profile changes

\section{1.はじめに}

近年，海岸保全対策として各地で養浜が行われて いるが，その手法は十分確立してはおらず，様々な 課題が残されているのが現状である. 宇多・石川 ${ }^{11}$ は, 沿岸漂砂が卓越する海岸において, 自然環境や 海浜利用への影響を抑えつつ養浜により早期に砂浜 を回復する手法として，漂砂の上手側にバーム高程 度の高さで砂を投入し，波の作用による投入砂の広 がりを期待する手法を提案した。 しかし多くの養浜 では高盛土形式で養浜砂が投入され，さらにその天 端を重機により敷き均す工事が行われている，本研 究で対象とする駿河海岸にあっても，侵食対策とし て大井川河口部の土砂約 6 万 $\mathrm{m}^{3} / \mathrm{yr}$ を用いた養浜が 行われてきたが，その方法は後浜において T.P.+5m までの高盛土形式で養浜を行う手法であった。この ような状況下で, 2009 年 10 月 8 日に台風 18 号が 駿河海岸に襲来し, $\mathrm{H}_{1 / 3}=6.51 \mathrm{~m}, \mathrm{~T}=12.8 \mathrm{~s}$ （駿河海洋 観測塔）の高波が作用した。この結果，台風後の現 地調査によれば，堤防天端と養浜盛土の天端高との 標高差が小さい場所では, 堤防天端を越えた越波や
陸側への礫の打ち込みが観察された。また, 駿河海 岸の測線 No. 13 付近の消波堤が並べられた区域では 消波堤開口部において高波の作用により高さ $1.7 \mathrm{~m}$ の浜崖形成も観察された。本研究では, 台風 18 号 来襲前後の 2009 年 3 月と 10 月に実施したレーザー による前浜地形測量結果をもとに，まず台風来襲前 後の前浜の地形変化について調べた. 次に, 堤防天 端と養浜盛土の天端高との標高差が小さい場所で起 こる越波, さらには盛土養浜時における浜崖形成に ついて, 現地踏查や現地データの分析に加え等深線 変化モデルと数值波動水路を用いて検討した.

\section{2. 台風 18 号後の海岸現地踏査}

台風18号による高波の作用の結果，背後地一の越 波とともに盛土養浜区間での浜崖形成が観察された。 例えば, 図-1は台風来襲後の吉永放水路西側の海岸 状況であるが，盛土養浜により嵩上げされた後浜と， 堤防天端との比高が小さな場所では, 堤防天端を越 えて陸側に礫が打ち込まれた。一方, 礫の打ち込み 


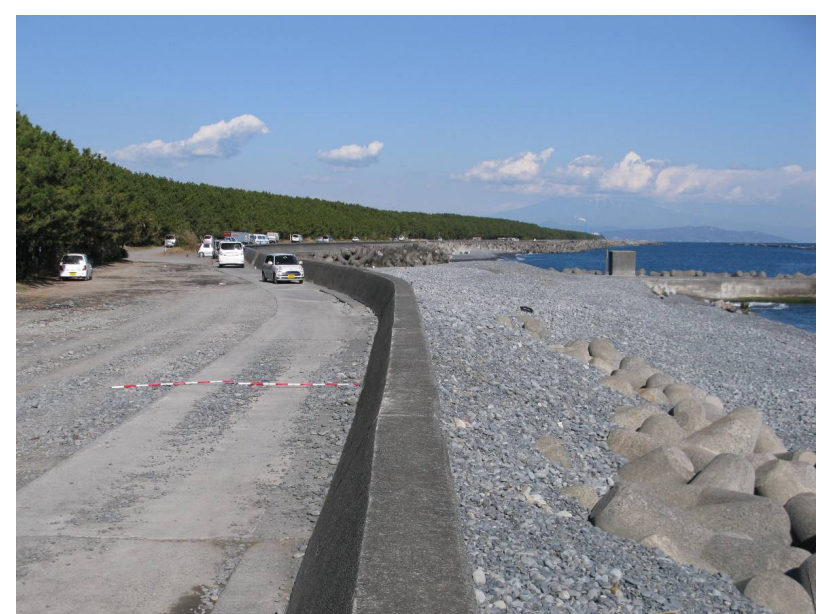

図-1 吉永放水路西側の堤防背後への砂磎の 打ち込夕状況（2010年1月8日）

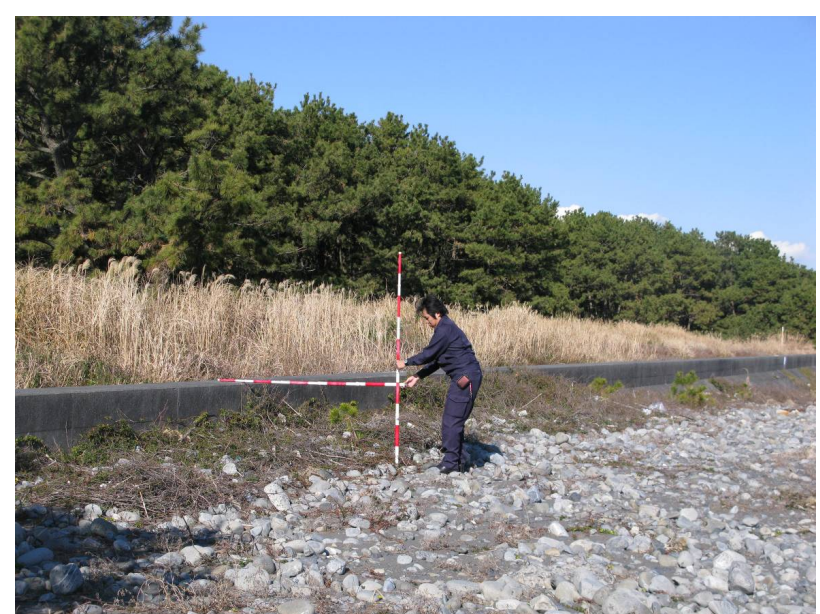

図-2 背後地への越波が生じた場所の堤防天端 と地盤との比高（2010年1月8日）

がない箇所では，堤防天端と後浜の間にかなりの標 高差があった。図-2は吉永放水路の北側で撮影した ものであるが，ここでは盛土養浜の結果後浜高が高 く，かつ平坦で堤防天端高と差が小さかったため, その背後地では越波が起こり塩分の侵入により植物 が枯れているのが見出された（図-3）。さらに図-4 は栃山川東側の測線No. 13付近での浜崖形成状況を 示す．後浜が高く，固く締め固められた養浜区域で は，高波浪により $1.7 \mathrm{~m}$ の浜崖が形成され，海岸利用 に支障を来たしていた。このように盛土養浜時の地 盤が平坦で，堤防天端との比高が小さい場合越波が 助長され，同時に浜崖形成が著しいとの観察結果が 得られた.

\section{3. 台風18号時の高波浪に起因する地形変化}

\section{(1) 区域Aでの変形}

レーザーによる前浜地形測量の観測区域は図-5に 示す $A \sim G$ の矩形区域であるが，自然海浜の区域 $A$ と 盛土養浜が行われている区域Bを対象とした。また 区域A，Bから測線No. 9 とNo. 36を選び，2007年1月実

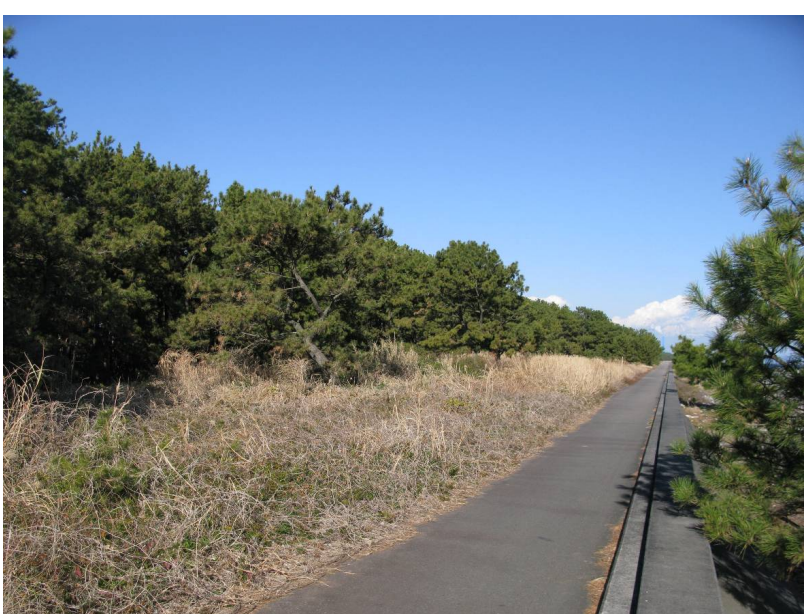

図-3 部分的に枯れた植物より推定される背 後地の越波痕跡（2010年1月8日）

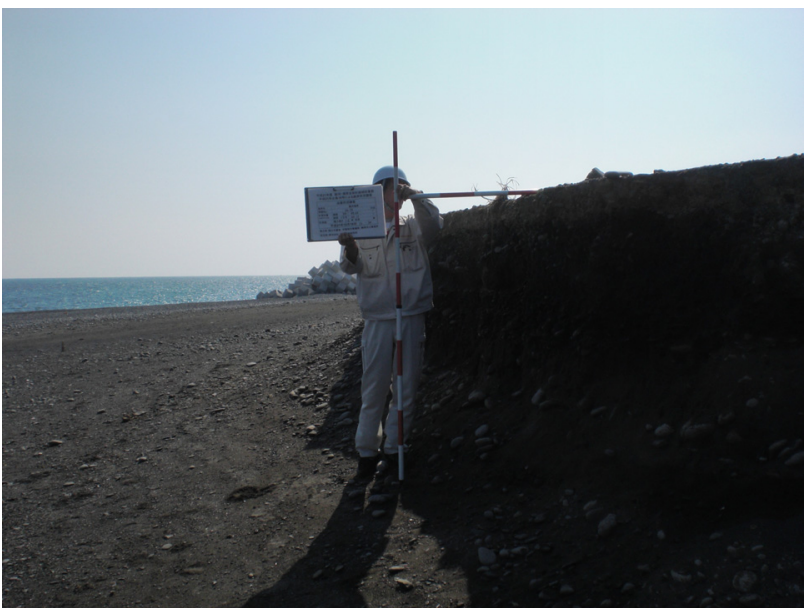

図-4 杤山川東側（測線No. 13）における浜崖 形成状況（2009年10月14日）

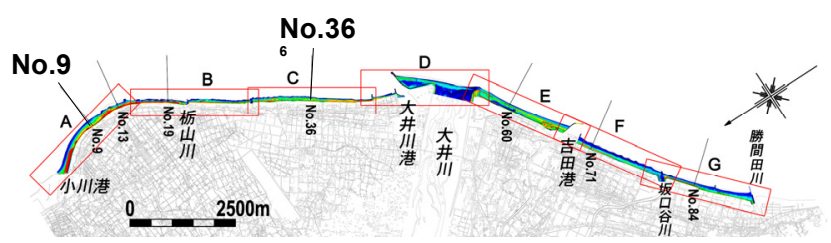

図-5 区域 $A \sim G$ と測線No. 9 と No. 36 の配置

施の深浅測量データも併せて縦断形の変化を調べた まず，区域Aの海浜形状と地形変化量を図-6，7に示 す. 図-6のNo.9以南で見られる波状の海岸線はその 沖に離岸堤が設置されていることによる。また2009 年10月においてNo. 9 とNo. 13間に形成された矩形状 の堆積域は盛土による。海浜地の標高はほぼ5mにあ るが, 小川港隣接部では埋め立てが行われたため約 $7 \mathrm{~m}$ と高まる。図-7の地形変化図で見られる最も著し い特徴は, 汀線に沿って約 $2 \mathrm{~m}$ の堆積が起きたことで ある。図-8は2010年1月15日におけるNo.9の前浜状 況を示すが，汀線近傍に高い碟堤が形成されており， 礫堤頂部は沿岸方向に一様な高さを有していた。図 -9はNo. 9の縦断形変化を示すが，2009年3月には高 さ2mの礫堤であつたが，高波浪の作用により礫堤の 頂が陸向きに $10 \mathrm{~m}$ 移動するとともに高さが $2.8 \mathrm{~m}$ ま゙ 高まった。このことから図-7に示す汀線に沿った細 
(a) 2009年3月

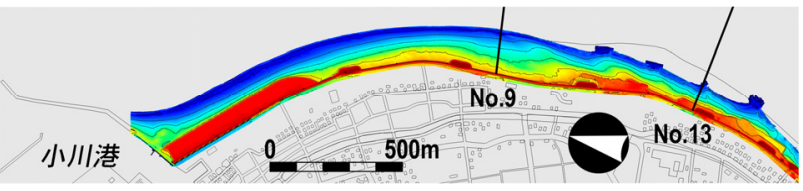

（b）2009年10月

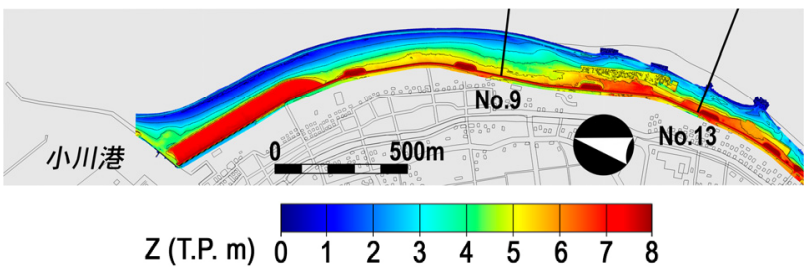

図-6 2009年3月と10月の海浜形状（区域A）

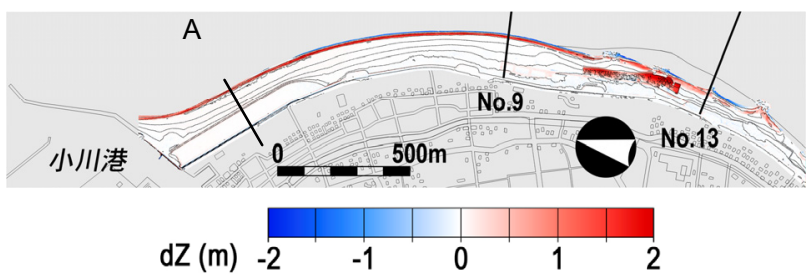

図-7 2009年3月～10月の地形変化量（区域A）

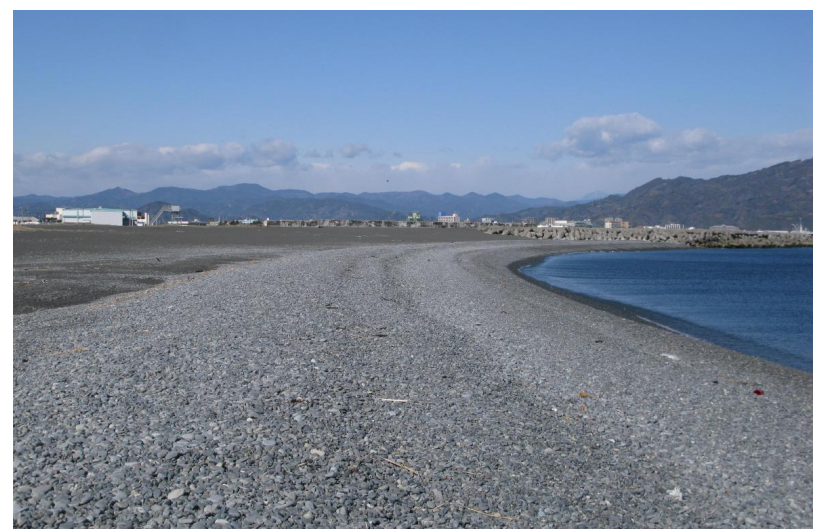

図-8 バーム頂部から北側を望む（2010年1月15日）

長い堆積は碟バームの形成に起因することが明らか になった。

次に，2010年3月測量のNo. 9の縦断形と $\mathrm{d}_{50}$ および 粒度組成の水深方向分布を図-10に示す。碟堤は汀 線のすぐ陸側に形成されたが，汀線から-5mまでの 海底勾配は $1 / 6$ と急であり，-5m以深では $1 / 3$ とさら に急になる。海底勾配が急なため $\mathrm{d}_{50}$ むきく， バーム頂付近では $20 \mathrm{~mm}$ であり，汀線ではいったん $10 \mathrm{~mm}$ 程度と小さくなるが，海面下では増大し， $-5 \mathrm{~m}$ 以深では約 $40 \mathrm{~mm}$ と大きなる。粒度組成で見ても海 底面全体が砶で覆われている。このようにNo.9では 礫が集中的に堆積しており，それが高波浪の作用で 岸向きに移動し, 同時に遡上高の増大にあわせて バーム高が上昇するという結果が得られた。

\section{(2) 区域Bでの変形}

区域Bの海浜形状と地形変化量を図-11，12に示す. この付近では消波堤が連続的に並び，しかもNo. 36 以南では盛土養浜が行われた結果，堤防前面の地盤

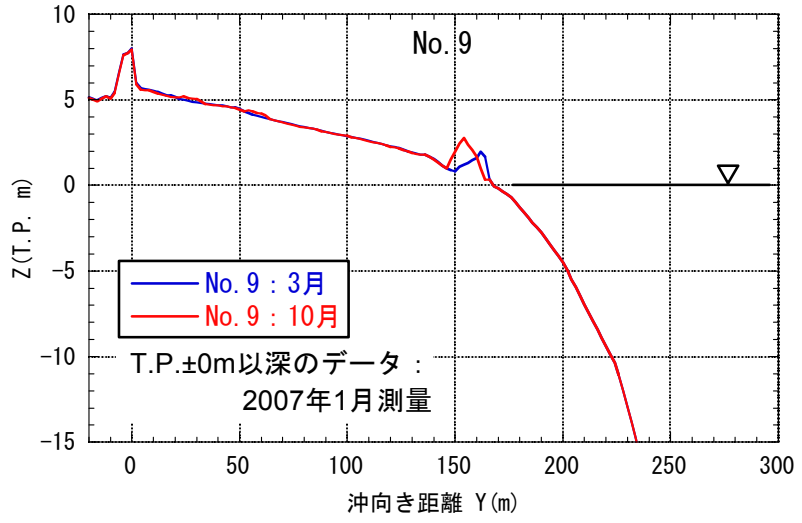

図-9 測線No. 9の縦断形変化

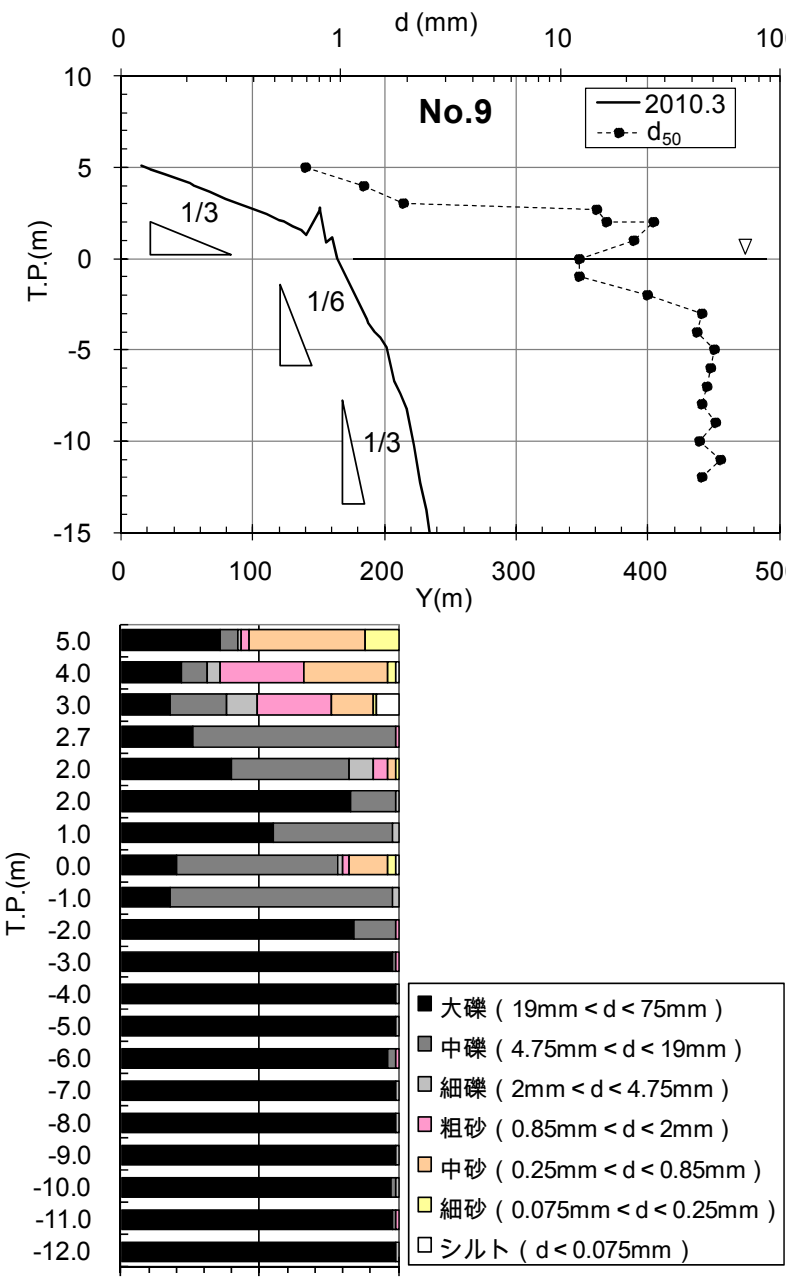

$0 \% \quad 50 \% \quad 100 \%$ 粒度組成

図-10 測線No. 9 の縦断形と $d_{50}$, 粒度組成の水深方 向分布

高が $5.5 \mathrm{~m}$ と高い。海岸線が消波堤で固定されている ため地形変化は小さいが，消波堤の開口部では侵食 が確認できる。図-13は侵食が起きたNo. 36の縦断形 変化を示す. 堤防前面から高盛土されたのり面は, 汀線から $2 \mathrm{~m}$ ま゙が侵食され，一部の土砂は打ち上げ られたものの大部分は流出し, 浜崖が形成された.

図-14は，顕著な前浜侵食が観察されたNo. 36の縦 
(a) 2009年3月

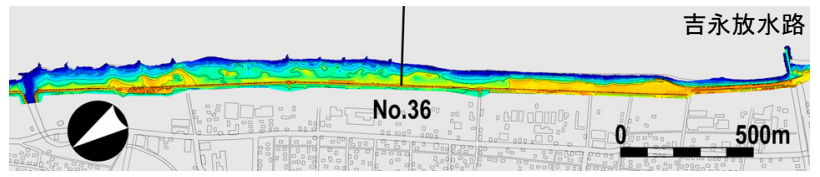

(b) 2009年10月

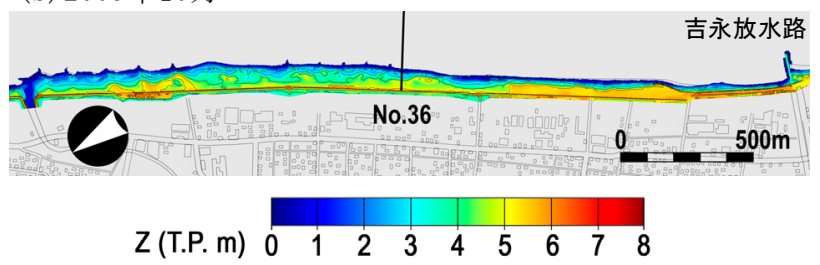

図-11 2009年3月と10月の海浜形状（区域C）

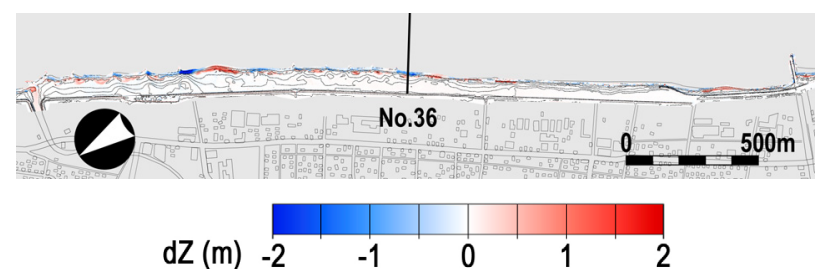

図-12 2009年3月～10月の地形変化量（区域C）

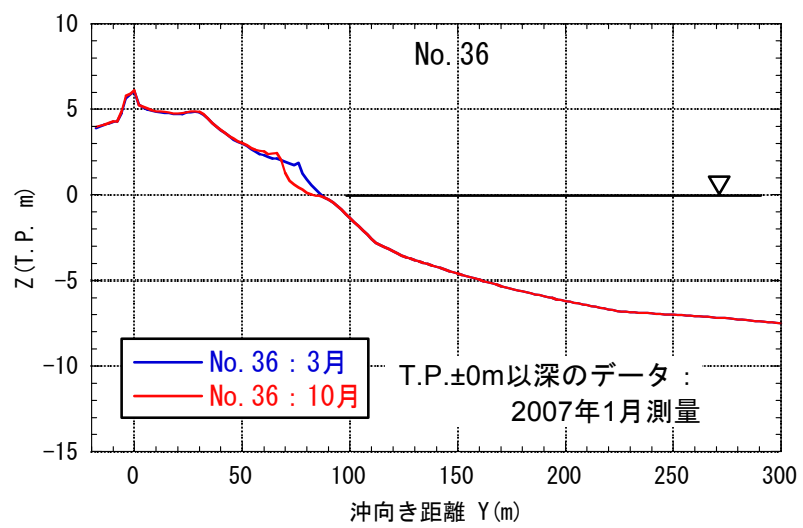

図-13 測線No. 36の縦断形変化

断形と $\mathrm{d}_{50}$, および粒度組成の水深方向分布を示す. この測線では前浜から-4mまでは $1 / 6$ と急勾配である が，-5m以深ではほぼ $1 / 90$ と非常に緩くなる。 $\mathrm{d}_{50}$ の 水深方向分布はこの勾配変化にきれいに対応し，$1 \mathrm{~m} よ り$ 陸側では砶分が多いのに対し，-2m以深では 礫は存在せず海底面は細砂と中砂のみによって覆わ れている。また，侵食が起きた汀線〜 $2 \mathrm{~m}$ 間は碩のみ で覆われているのではなく，中砂が平均で $48 \%$ (T.P. $\pm 0,1,2 \mathrm{~m}$ の平均) 含まれている. 宇多ら ${ }^{2)}$ が 西湘海岸の海浜変形で明らかにしたように，高波浪 の作用時には砂磕の持つ平衡勾配が一時的に緩くな り，沖向き移動が起こることを考慮すれば，図-13 に示した前浜の侵食ではこの点を考慮すれば説明が 可能と考えられる.

\section{4. 高波浪時の前浜侵食の機構}

\section{（1）等深線変化モデルによる検討}

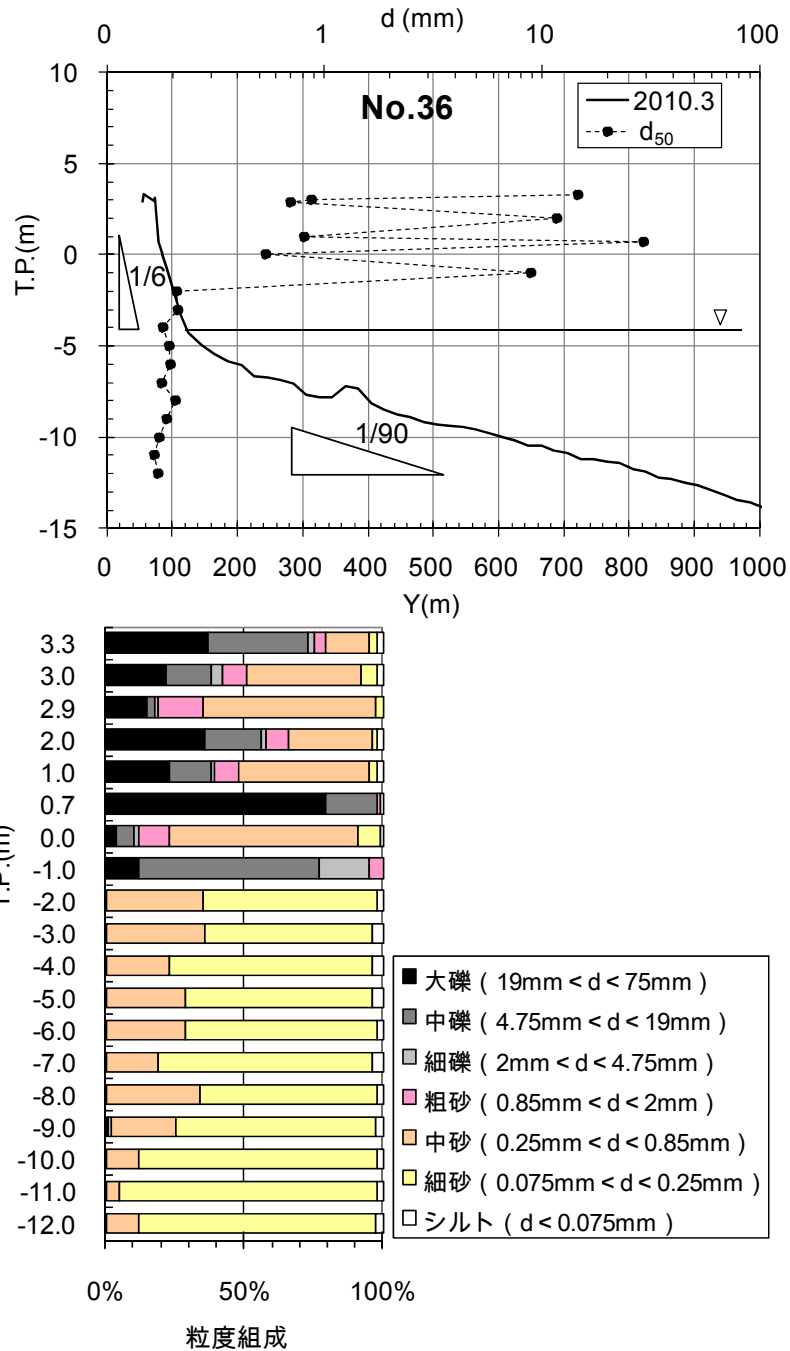

図-14 測線No. 36 の縦断形と $\mathrm{d}_{50}$, 粒度組成の水深 方向分布

盛土養浜個所での浜崖形成機構に関し，No. 36の 縦断形変化を対象として等深線変化モデルを用いて 検討した．ここでは粒度ごとの移動特性ではなく， 前浜全体を対象として高波浪の作用時砂礫の平衡勾 配が小さくなり, 沖向きに砂碟が流出して変形が起 こるという単純なモデル2）用いた。水深方向の計 算範囲は $Z=+5.5 \mathrm{~m} \sim-20.5 \mathrm{~m}$ とした。また，粒径は2 成分とし，-5m以深に堆積している細砂・中砂を代 表する粒径 1 を $\mathrm{d}_{1}=0.25 \mathrm{~mm},-5 \mathrm{~m}$ 以浅の前浜の砂を代 表する粒径 2 を $\mathrm{d}_{2}=2 \mathrm{~mm}$ とし, 試行計算に基づき, 前 浜勾配が $1 / 6$ から $1 / 18$ まで緩くなると仮定した。波 浪条件としては, 台風時の有義波高の最大值 $\mathrm{H}_{1 / 3}=6.51 \mathrm{~m}$ 与え, また波による地形変化の限界水 深h とめて示す.

No. 36の再現計算の結果を図-15に示す。初期の汀 線付近の勾配 $1 / 6$ と沖合の $1 / 90$ が，高波浪時に $1 / 18$, $1 / 270$ と緩まると仮定すると，波の作用により前浜 が侵食され，5mの高さの盛土との間に浜崖が形成さ れる。なお，図-15は前浜の変形を見やすくするた め計算範囲を切り出している. 実際は図の右端を通 過して水深の大きな部分への砂移動も起きているの 
表-1 計算条件

\begin{tabular}{|c|c|}
\hline 数值計算手法 & 粒径を考慮した等深線変化モデル ${ }^{3)}$ \\
\hline 計算ケース & 大井川工区 測線 No.36 \\
\hline 代表粒径と平衡勾配 & $\begin{array}{l}\text { 代表粒径 }(2 \text { 粒径 }) \text { と平衡勾配 } \\
\text { 粒径 } 1: \text { 細粒 } \\
\text { 代表粒径 } \mathrm{d}_{1}=0.25 \mathrm{~mm} \\
\text { 常時平衡勾配 } \tan \beta_{1}=1 / 90 \\
\text { 高波浪時平衡勾配 } \\
\tan \beta_{2} \fallingdotseq 1 / 3 \tan \beta_{1} \\
\text { 粒径 } 2: \text { 粗粒 } \\
\text { 代表粒径 } \mathrm{d}_{2}=2 \mathrm{~mm} \\
\text { 常時平衡勾配 } \tan \beta_{1}=1 / 6 \\
\text { 高波浪時平衡勾配 } \\
\tan \beta_{2} \fallingdotseq 1 / 3 \tan \beta_{1}\end{array}$ \\
\hline 初期地形 & $\begin{array}{l}-5 \mathrm{~m} \text { 以浅 } 1 / 6 \\
-5 \mathrm{~m} \text { 以深 } 1 / 90\end{array}$ \\
\hline 初期粒径の含有率 & $\begin{array}{ll}Z>-5 m: \text { : 細粒 } \mu_{1}=0, & \text { 粗粒 } \mu_{2}=1 \\
Z<-5 m: \text { : 細粒 } \mu_{1}=1, & \text { 粗粒 } \mu_{2}=0\end{array}$ \\
\hline 入射波条件 & 砕波波高 $\mathrm{H}_{\mathrm{b}}=6.5 \mathrm{~m}$ \\
\hline 漂砂量係数 & $\begin{array}{l}\text { 沿岸漂砂量係数 } \mathrm{K}_{\mathrm{x}}=\mathrm{A} / \mathrm{sqrt}(\mathrm{d}) \\
\text { 係数 } \mathrm{A}=1.0 \\
\text { 岸沖漂砂量係数 } \mathrm{K}_{\mathrm{z}}=0.01 \mathrm{~K}_{\mathrm{x}}\end{array}$ \\
\hline 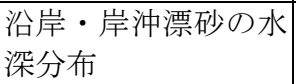 & 宇多・河野の 3 次式 \\
\hline $\begin{array}{l}\text { 波による地形変化の } \\
\text { 限界水深 }\end{array}$ & $\mathrm{h}_{\mathrm{c}}=12 \mathrm{~m}$ \\
\hline バーム高 & $\mathrm{h}_{\mathrm{R}}=4.5 \mathrm{~m}$ \\
\hline $\begin{array}{l}\text { 土砂落ち込みの限界 } \\
\text { 勾配 }\end{array}$ & 陸上 $1 / 2$, 水中 $1 / 3$ \\
\hline 交換層の幅 & $\mathrm{B}=10 \mathrm{~m}$ \\
\hline 計算等深線範囲 & $Z=+5.5 \mathrm{~m} \sim-20.5 \mathrm{~m}$ \\
\hline 計算メッシュ & 鉛直方向 $\Delta \mathrm{Z}=1 \mathrm{~m}$ \\
\hline 計算時間ピッチ & $\Delta=0.1 \mathrm{hr}$ \\
\hline 計算ステップ数 & 10000 ステップ \\
\hline 境界条件 & \begin{tabular}{|l} 
岸沖端 : $\mathrm{q}_{\mathrm{z}}=0$ \\
(漂砂の流入出なし)
\end{tabular} \\
\hline
\end{tabular}

表-2 CADMAS SURF の計算条件

\begin{tabular}{l|l}
\hline 項目 & 設定值 \\
\hline \hline 入射波高 $(\mathrm{m})$ & 5.15 \\
\hline 周期 $(\mathrm{s})$ & 11.0 \\
\hline 潮位 $(\mathrm{m})$ & 1.65 \\
\hline 成分波数 & 512 \\
\hline 計算領域 $(\mathrm{m})$ & $800 \times 40$ \\
\hline 格子間隔 $(\mathrm{m})$ & 水平 $: 0.5 \sim 2.0$ \\
\hline 格子数 & 鉛直 $: 0.2 \sim 0.4$ \\
\hline 計算時間 & $775 \times 132$ \\
\hline 断面地形 & $500 \mathrm{~s}$ \\
\hline 出力条件 & No.13, No.36 \\
\hline
\end{tabular}

表-3 CADMAS SURF による測線 No.36 における 越波流量の計算結果

\begin{tabular}{l|c|c|c|c|c}
\hline 断面 & $\begin{array}{c}\text { 越波 } \\
\text { 水位 } \\
(\mathrm{m})\end{array}$ & $\begin{array}{c}\text { 延 } \\
\text { 長 } \\
(\mathrm{m})\end{array}$ & $\begin{array}{c}\text { 水量 } \\
\left(\mathrm{m}^{3}\right)\end{array}$ & $\begin{array}{c}\text { 湛水 } \\
\text { 時間 } \\
(\mathrm{s})\end{array}$ & $\begin{array}{c}\text { 越波流量 } \\
\left(\mathrm{m}^{3} / \mathrm{s} / \mathrm{m}\right) \\
\left(\begin{array}{l}\text { 現況に対する } \\
\text { 比率 })\end{array}\right.\end{array}$ \\
\hline \hline 現況 & 0.3 & 41 & 12.3 & 350 & 0.035 \\
\hline $\begin{array}{l}\text { 後浜高 } \\
\text { を下げ } \\
\text { た場合 }\end{array}$ & 0.2 & 41 & 8.2 & 350 & $0.023(66 \%)$ \\
\hline
\end{tabular}

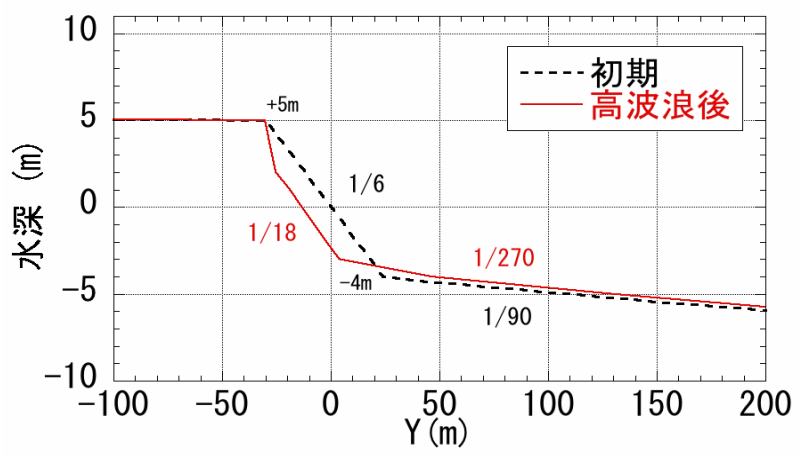

図-15 台風18号来襲時の地形変化の再現計算（No. 36）

で，図示する範囲では土砂収支は成立していない. このように，本モデルにより対象断面における高波 浪作用時の前浜地形変化の特徵を概ね再現すること ができる。そこで次に後浜高の違いによる地形変化 の相違について検討した。予測計算は，後浜高を T.P.+3，4，5mと変えた（ケース $1 〜 3)$. 図-16には 計算結果を示す。盛土の高さが低い場合，高波浪に より前浜は削り取られるものの浜崖は形成されない。 しかし後浜高が高くなるに従い浜崖の高さが増大す ることが分かる。すなわち, 海浜利用上障害となる 高い浜崖の形成防止のためには，盛土高を通常時の 波の遡上高（バーム高）までとするのが望ましいと 考えられる.

\section{（2）数值波動水路（CADMAS-SURF）による検討}

現地踏査結果によれば，越波防止には堤防天端と 後浜間に適切な標高差が必要と考えられる。そこで この効果を調べるために，No. 36を対象として現況 断面と, 後浜高をT.P. $+3 \mathrm{~m}$ まで掘り下げ，その土砂 を前浜に養浜した場合における越波状況の差につい て数值波動水路（CADMAS-SURF）を用いて検討した。 計算条件を表-2に示す。図-17には越波計算の結果 を示す.また, 堤防背後のプールに流入した水量を 水位 $\times$ 延長 $(42 \mathrm{~m}) \times$ 単位幅 $(1 \mathrm{~m})$ で求め, 湛水ま でに要した時間より越波流量を求めた結果を表-3に 示す。これより現状の盛土養浜形状ではNo. 36の越 波流量 $0.035 \mathrm{~m}^{3} / \mathrm{m} / \mathrm{s}$ に対し，後浜高を下げた場合は $0.023 \mathrm{~m}^{3} / \mathrm{m} / \mathrm{s}$ と $66 \%$ に低減した。これより後浜高を 下げて堤防天端高との差を設けることが高潮対策と して有効なことが分かった。 
（a）ケース $1 ：$ 盛土天端高 $=3 \mathrm{~m}$

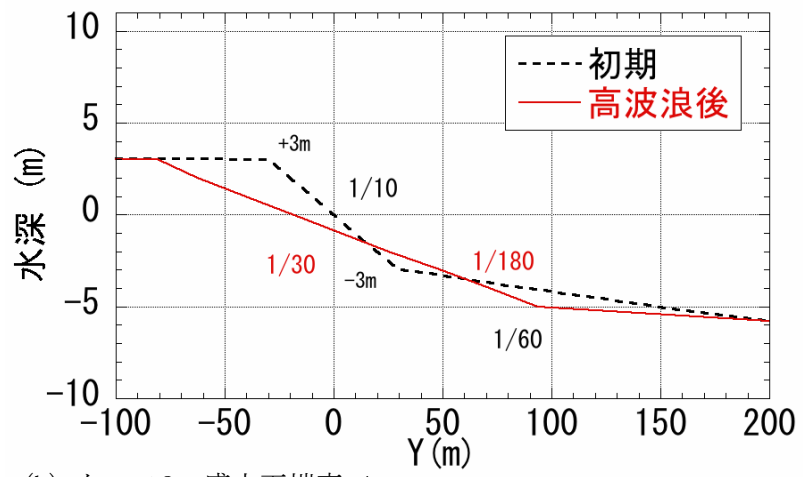

(b) ケース 2 : 盛土天端高 $=4 \mathrm{~m}$

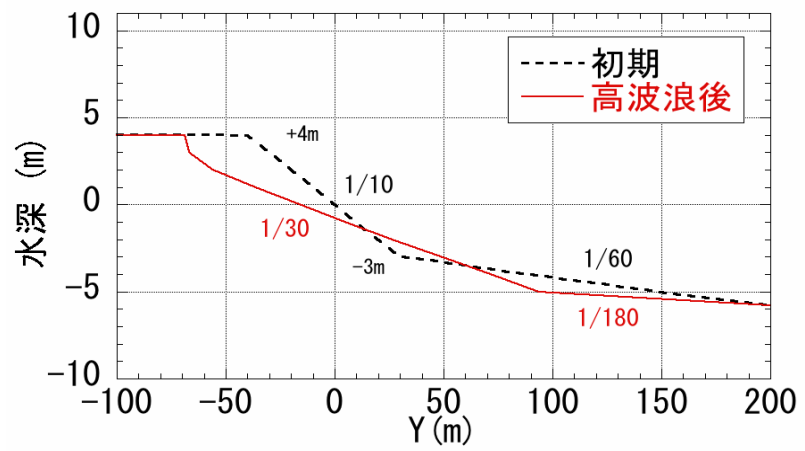

(c) ケース 3 : 盛土天端高 $=5 \mathrm{~m}$

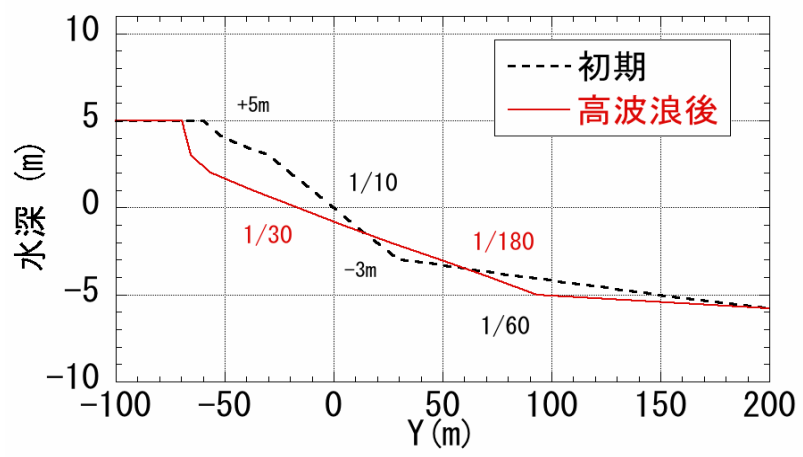

図-16 盛土養浜の高さを変えた場合の浜崖形成状 況の差（計算）

\section{5. まとめ}

駿河海岸では2009年10月8日に台風18号が襲来し, $\mathrm{H}_{1 / 3}=6.51 \mathrm{~m}, \mathrm{~T}=12.8 \mathrm{~s}$ の高波が作用した。このとき海 浜材料が碟で構成されている駿河海岸では礫の急激 な岸向き移動が起こり，バーム高が台風前の $2 \mathrm{~m} か ら$ $2.8 \mathrm{~m}$ まで上昇し，バームの形成位置が陸側に約 $10 \mathrm{~m}$ 移動したことが分かった。また，前浜が礫で構成さ れた急勾配海岸において, 後浜に盛土養浜を行った 場合，高波浪の来襲によって前浜とともに盛土部が (a) 現況

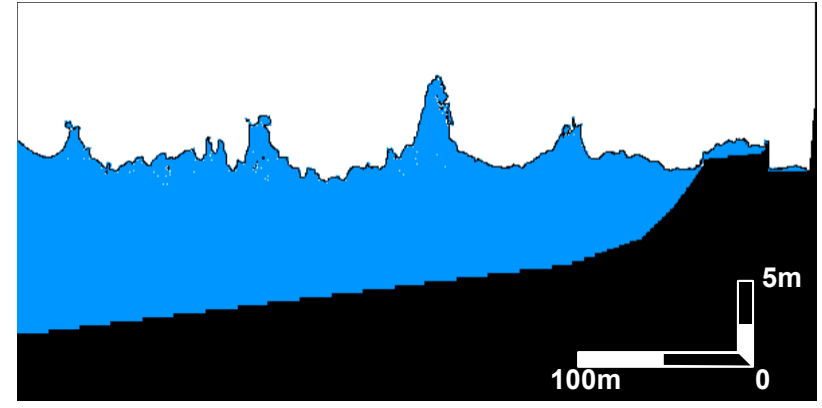

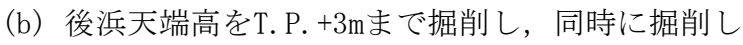
た土砂を前浜に養浜した場合

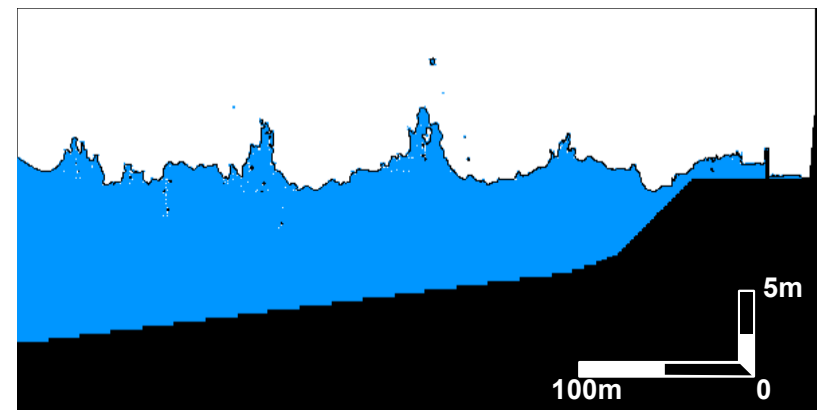

図-17 CADMAS SURFによる台風18号来襲時の越波状況 （現況と掘削時）

削り取られ浜崖が形成されることが現地踏査と数值 モデルにより明らかになった。高波浪による地形変 化の発生頻度は小さいが, 盛土養浜は浜崖の形成要 因のひとつとなる。浜崖形成を避けるには, 盛土養 浜時の後浜天端高を現地のバーム高程度とすること が望ましいと考えられる。 さらに，後浜高が高く堤 防天端との差が小さいと，越波が助長されることも 明らかになった。高潮対策には盛土養浜による後浜 の嵩上げ時にその高さあまり高めず，堤防天端との 間に標高差を設けることが有効である.

\section{参考文献}

1) 宇多高明, 石川仁憲：「実務者のための養浜マニュア ル」，（財）土木研究センター，p. 170. 2005.

2) 宇多高明, 丸山將吾, 高野弘之, 芹沢真澄, 三波俊郎, 石川仁憲，宮原志帆：T0709 号時の高波浪による西湘 海岸の急変形の再現計算, 海岸工学論文集, 第 56 巻, pp. 561-565, 2009.

3) 熊田貴之, 宇多高明, 芹沢真澄, 小林昭男：混合砂に よる養浜時縦断形予測モデル，海岸工学論文集，第 50 巻, pp. 596-600, 2003. 